joining the botanists in the development of an accurate nomenclature. For while some sneer at nomenclature as a trivial matter and of no importance, it must be remembered that nomenclature is the expression of ideas, and ideas are of much importance.

University of Minnesota. Conway MacMillan.

\section{Photographs of Scientific Men.}

A NOTE in your recent issue having to do with a request for the photographs of American botanists suggests that an appeal made through the columns of Science is likely to aid a collection made by myself. Some six or seven years ago, finding great difficulty in procuring the portraits of American scientists, I began gathering the photographs of the members of the National Academy of Science, and last year deposited in the Smithsonian Institution a collection of mounted portraits (with mounted autograph letters) of every member of our academy save two. This collection forms part, I believe, of the exhibit of the Smithsonian Institution at the Chicago Columbian Exhibition. The two portraits which are needed to make the set entirely complete are those of John Henry Alexander (1812-1867) of St. James College, Maryland, and later of the U. S. Coast Survey, and Jonathan Homer Lane (1819-1880), long connected with the U. S. Coast Survey and the U. S. Patent Office. I should be glad to obtain photographs of the two scientists or to miake arrangements for the copying of any likeness of them known to exist.

640 Madison Avenue, New York City, May 18, 1893.

Marcus Benjamin.

\section{The Palæolithic Man in Ohio.}

IN the second number of The Journal of Geology, Mr. Wm. H. Holmes has resumed his polemic against the evidence of the existence of palæolithic man in North America with a long article upon "Traces of Glacial Man in Ohio." Like his previous article upon the Trenton finds, this, too, is characterized by the kind of reasoning, which a correspondent of Science has called the argument ad ignorantiam, i. e., because he has failed to find palæolithic implements in a certain locality, therefore no one else has ever found them there. The present article, however, exhibits also a striking example of what might be called " the argument by monopoly." Mr. Holmes produces two fanciful cuts to show how the top of a gravel pit might have slid down so as to bury Indian relics coming from the surface; but he cannot see any sense in Professor Wright's preparing a plate to show precisely where in the same gravel-pit Mr. Mills actually found"the object in dispute.

But the great difficulty about Mr. Holmes's discussion of this subject is that he has no correct appreciation of what a palæolithic implement really looks like. This is not to be wondered at when we refiect that his studies in " archæology" have been limited to investigations of the subject of "native art." $\mathrm{He}$ says "close analogies of form between Indian rejects and some varieties of European palæolithic objects are too common to permit the attachment of much value to this feature of this or any other similar find." Accordingly he proceeds to prepare a plate containing, besides the object discovered by Mr. Mills, of which he gives as good a copy as he can have made, four unfinished Indian celts found by him fifty miles away. Of these objects he says, "they correspond very closely in material and appearance with the New Comerstown specimen, as will be apparent from an examination of the plate. The figures are presented without identification in order that the student may, by an effort to distinguish them, convince himself of the similarity of the supposed paleolith to the quarry-shop rejects of the region."

Now I undertake to assert that any competent student of prehistoric archæology who has studied the subject in the Old World, where palæolithic implements have been found in large numbers, will have no difficulty in discriminating upon Mr. Holmes's plate between the true palæolithic implement and the four unfinished Indian celts placed beside it. All plates, however, fail to give a fair representation of solid objects like these, from the necessity of the case. They must be handled to be understood. The four unfinished celts resemble those previously figured by Mr. Holmes in describing the objects he discovered near Washington, where I have myself found similar objects several years ago. I repeat here, what I have said in another place, " no trained archæologist would hesitate for a moment to pronounce that the objects figured in the article entitled ' $A$ Quarry Workshop' (American Anthropologist, Vol. III., plate 4) do not bear the slightest resemblance to real palæolithic implements."

I conclude this note with what I have already urged to the readers of Science, that " only a jury of the acknowledged prehistoric archæologists of the world is competent to pronounce jurgment upon this question." HENRY W. HAYNES.

Boston, May 13, 1893.

\section{BOOK-REVIEWS}

Mineral Resources of the United States. 1891. By David T. DAY. Washington, D. C., Department of the Interior, Government Printing Office. 1893. 630 p.

IT is somewhat unfortunate that these volumes cannot be more promptly produced, the late date of their issue impairing materially the value of the statistics contained. But in spite of this they are always welcome, and together-the present volume being the eighth in the series - they form a valuable component of every library. The arrangement is the same as in previous issues, and we find the familiar names of Birkinbine, Kirchoff, Weeks, Parker, and others under their respective specialties. Mr. Parker's statistical article on coal is exhaustive, occupying nearly 200 pages in all, and is supplemented by the articles on coke, petroleum, and natural gas by Mr. J. D. Weeks. Mr. Wm. C, Day continues his paper on stone from the "Resources" for 1889-90. An admirable and much-needed division appears upon the clay materials of the United States, written by Mr. Robert $\mathrm{T}$ Hill, and as this is in some respects the feature of the present volume an outline may not be out of place. Beginning with descriptive remarks, Mr. Hill passes on to the commercial classification, the origin and natural classification, residual or rock kaolins, and sedimentary or bedded clays. The sedimentary clays of the geological formations are given in natural sequence. The accessory minerals used in the clay industries are described and then the occurrence of clay materials by States.

Other interesting articles are those on natural and artificial cements, by Spencer B. Newberry, both descriptive and statistical, on precious stones by the expert, Mr. Geo. F. Kunz, and Mr. Packard's descriptive article on aluminum, the last including several pages on bauxite, with analyses and a sketch of the development in the South. Alabama, Georgia, and Arkansas are mentioned as containing the mineral, but Tennessee with its good promise, Virginia, and North and South Carolina are not spoken of.

An unfortunate slip of the binder has placed pages 49-64 inclusive between pages 32 and 33 , but in other respects the book is all that can be wished for.

C. P.

William Gilbert of Colchester, On the Loadstone and Magnetic

Bodies. A translation by P. Fleury Mottelay. New York, John Wiley \& Sons.

A RATHer acrimonious discussion between Professor S. P. Thompson and Messrs. Wiley \& Sons has attracted even more attention to this book than it would otherwise have received. It will be remembered that the Gilbert Club was formed in England a few years ago, and that one of the objects of their existence was the publication by subscription of Gilbert's works. Professor Thompson was one of the committee on publication, and the matter seems to have been left mostly to him. From various causes, one of which was possibly the fact that the latter is translating and editing a number of books on his own account, the publication of the Gilbert Club has been delayed. Previous to the determination of the club to undertake the publication of Gilbert's work, Mr. Mottelay had been seized with the same idea, and, as neither he nor his publishers were in any way infringing on the rights of the Gilbert Club, the work has recently been 